\title{
白金電極の表面酸化届について
}

\section{On the Surface Oxide Layer of Platinum Electrode}

\author{
大 橋 邦 夫*, 佐々木和夫*, 長 浦 茂 男* \\ Kunio OHashi, KazLo SASaki, Shigeo Nagaura
}

\section{1 緒言}

アノード酸化によって，白金電極表面に酸化凰が生成 することは広く認められていることで, ${ }^{2) 11)}$ その組成は $\mathrm{PtO}$ ，または $\mathrm{PtO}_{2}$ であり，厚みが単分子圆程度である ことなどの点で促来の諸説は一致している．Lingane ら”は電解的に生成した酸化層を化学的に溶解し，溶液 の分光分析を行なって $\mathrm{Pt}(\mathrm{II}), \mathrm{Pt}(\mathrm{IV})$ の存在を認めた. それぞれは $\mathrm{PtO}$ および $\mathrm{PtO}_{2}$ なる表面酸化層住対灾す るもの之結論されている.しかし，白金極の表面酸化層 は酸素の化学吸着とする考元方も多〈6) 9\},11), 特に Giner $^{7}$ は, 白金の酸化物と, 電極表面の酸素の単分子 層とは区別すべきことを指摘している。

こうした諭議に対して早急に一義的な結論が光られる かどうかは疑問であるが，酸化層の存在することは事実 であり, その電気化学的挙動を詳細仅ることが, より 先決の䦓題であろう.

本報では三角波ポテンシオメトリーと，クロノポテン シオメトリーを行なって得られた結果について述べる。

\section{2 実 験亡結 果}

\section{1 実験方法}

2.1.1 三角波ボテンシオメトリー＼cjkstart定電位電解装置 （日西計器製）に，自製の機械装置をつけ，電位走查速 度を最大 $500 \mathrm{mV} / \mathrm{sec}$ まで任意に変化できるようにし た. 試験電極は直径 $1 \mathrm{~mm}$ の白金線を用いた. 電解り ウには $\mathrm{H}$ 型容器を用い, 対極室との間はガラスフィル ターで仕切った。電解液はずてて $1 N$ 硫酸とし窒素通気 によりあらかじめ溶存酸素の除去を行なった．照合電極 には飽和甘コウ電極を用いた，以下，報告の中の電位は すべて飽和甘コウ電極基準である.

2.1.2 クロノポテンシオメトリー 安定化した $250 \mathrm{~V}$ の直流電源を用い，直列に入れた大きな抵抗を介 して, 電解電流が一定となるようにした，電位一時間曲 線の記録にはオシロスコープを用いた，武験電極は直径 $1 \mathrm{~mm}$ の白金線をガラス管に封入し，その断面だけが電 解液に接するようにした。

\section{2 実験結果}

電位走查速度を $50 \mathrm{mV} / \mathrm{min}, 200 \mathrm{mV} / \mathrm{sec}$ にして得ら
れる電位-電流曲線を図 1,2 亿それぞれ示した。走查速 度の上䍙によって, 電位一電流曲線に顕著な形状変化の 生ずるととが示される。このような結果はKnorr ら がすで報告しており，低い電位域住ずる二つの電流 ピーク $\mathrm{a}, \mathrm{b}$ (または $\mathrm{a}^{\prime}, \mathrm{b}^{\prime}$ ) は吸着状態の異なる二種の 水素の酸化（または水素イオンの還元）に対応するもの 之解䣋されている。

図 2 におけるもう一つの特徴は, 同図に示した D お

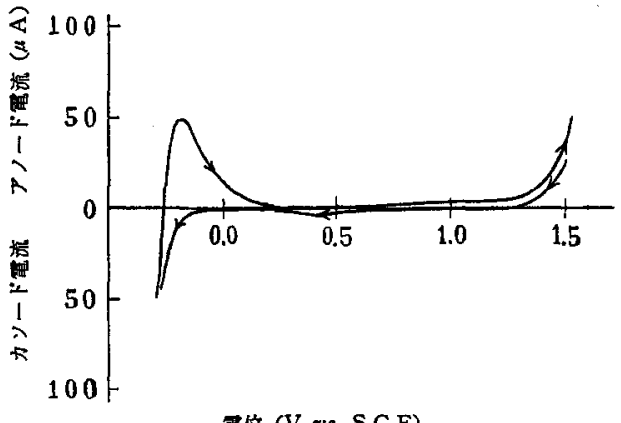

㫣位 (V vs. S.C.E)

图 $11 \mathrm{~N} \mathrm{H}_{2} \mathrm{SO}_{4}$ 中に和ける白金電極の電位一電流曲線 (電位走查速度 $50 \mathrm{mV} / \mathrm{min}$ )

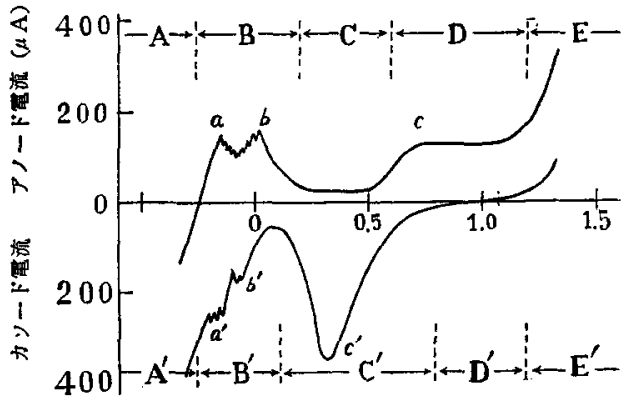

政 ( $\mathrm{V}$ vs. S.C.E)

因 $21 \mathrm{~N} \mathrm{H}_{2} \mathrm{SO}_{4}$ 中比拈引白金電極の電位一電流曲線 （電位走查速度 $200 \mathrm{mV} / \mathrm{sec）}$

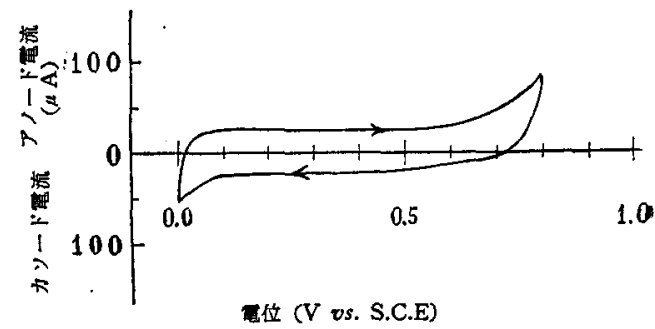

图3 $1 \mathrm{~N} \mathrm{H}_{3} \mathrm{SO}_{4}$ 中に打引る白金電極の電位一電流曲線 （電位域 $0.0 \sim 0.8 \mathrm{~V}$, 電位走查速度 $200 \mathrm{mV} / \mathrm{sec}$ ) 


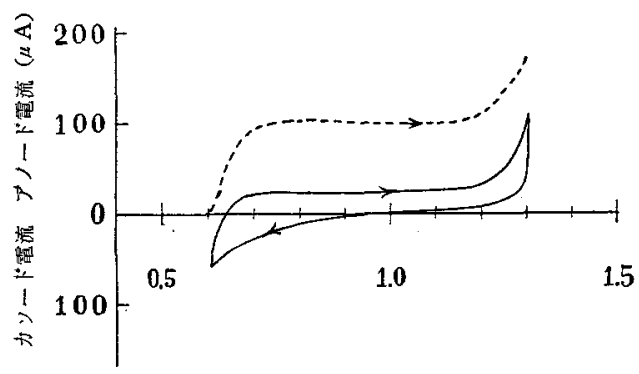

電位 (V. vs. S.C.E)

-... : 第一回目

図 $41 \mathrm{~N} \mathrm{H}_{2} \mathrm{SO}_{4}$ 中における白金電極の電位一電流曲線 (電位域 $0.6 \sim 1.4 \mathrm{~V}$ 電位走查速度 $200 \mathrm{mV} / \mathrm{sec}$ )

よび C'の領域に見られる、D 領域での電流増加は, 表 面酸化層の生成に基づくもので，C' 領域では，ての表 面酸化層の䢬元が起こったものと考光られる。電位走查 の上限を $0.8 \mathrm{~V}$ に限って得られる電位一電流曲線（図

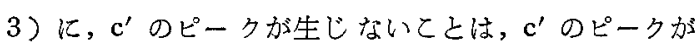
酸化層または酸素の還元を示す一つの証损である。

$0.6 \sim 1.4 \mathrm{~V}$ の電位域で走查を繰り返すと，図 4 の結 果が得られ，第一回目の走查だけが高い電流值を示すが (同図破楾)，第二回目以降は，一定の低い電流值を示す (同図実線)．第一回目のアノード走查では，表面酸化圈 の形成が行なわれるため大きなアノード電流を要する

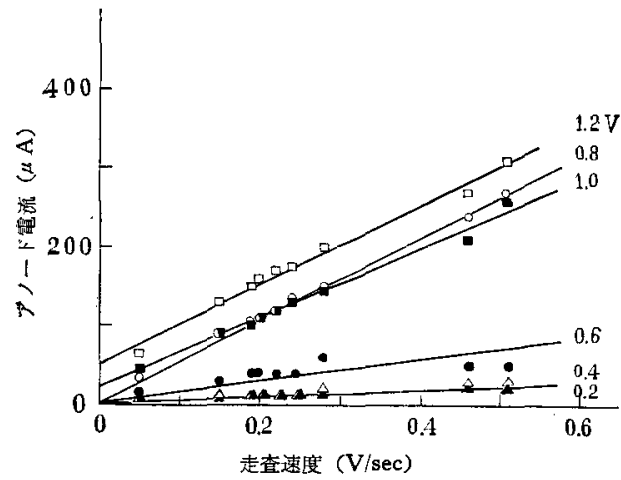

図 5 アノード電流と走查速度の関係
おけるアノード電流と走査速度の関係を示してある。い ずれの電位においても，電流と走查速度の閒には直線関 係が成立している。乙う配が微分容量の次元をもつこと は自明であらう．0.2〜0.4V の電位域では図 2 から見 ても何らの特異な反応が生じていない，てれらの電位域 に対応する図 5 の直線のとう配から，二重風容量を求め

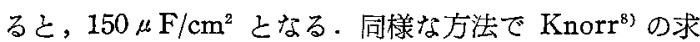
わた平均の二重層容量は $175 \mu \mathrm{F} / \mathrm{cm}^{2}$ で，われわれの結 果と一致している.

図 5 によると，1.0V と $1.2 \mathrm{~V}$ での測定值は，直線 を走查速度零に延長しても原点を通らない。乙れらの電 位では，走査速度に無関係な一定の定常電流か存在して いるととを示すものであろう。

電位-電流曲線を図的に区分積分するととにより，D 領域の種々な電位に至るまでに要するアノード過程の電 気量 $Q_{a}$ を求め表 $1-\mathrm{a}$ 亿示した， $0.5 \mathrm{~V}$ (酸化層生成 のはじまる電位) から表の上欄の電位までの電気量がそ の下の各欄に記されている，走查の上限電位と無関係 に，一定電位に上げるために要する電気量は一定である ととがわかる、上限電位までのアノード過程で生した酸 化層の還元は $0.2 \mathrm{~V}$ (電位一電流出線のカンード電流の 極小に刘応する) で完了すると考完られる. 表 1-bに， 種々な上限電位から走查を反転したときの還元電気量を 示した。上限電位から表の上橙の電位にまで下げるに要 する電気量がその下の各欄に記されている．酸化層の生 成の場合とは異なり，還元の進行状況と電位の関係は複 雑である.

表 1-a，1-b の結果を図示したのが図6である.上限 電位に対して，その電位まで上げるに要する電気量 $Q_{a}$ と, その電位から還元を行なって $0.2 \mathrm{~V}$ に至るまでの 電気量 $Q_{c}$ とがプロットしてある. 常に $Q_{a}$ は $Q_{c}$ よ りも大であるという結果が明らかである。図6の $Q_{a} の$ 值が，1.3V 以上で直線からずれているのは，これ以上 の電位で酸素発生が起こるためである。

図 7 に, 硫酸中での白金電極の典型的なクロノポテン

表 1-a 酸 化 電 気 量

が，0.6V までのカソード過程で は，生じた酸化層の還元は認めう るはどには起こらない。しわも， 表面酸化層は学分子層の程度以上 には成長しないから，第二回目以 降の走査ではアノード電流が激減 するちのと解される。しかし，二 回目以降でもアノード過程の電流 は完全には零とはならず一定值を 示している．この点は後に触れ 万.

図 5 には，走查域を $-0.22 \sim$ $1.4 \mathrm{~V}$ としたときの種々の電位に

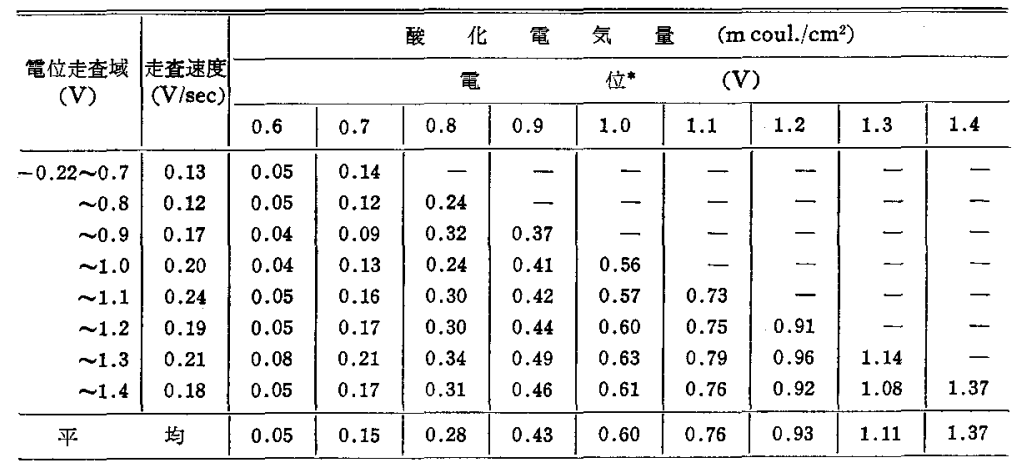

* $0.5 \mathrm{~V}$ からこの電位まで䤒化電気量がをの下の各欄に記されている。 
表 1-b 還元電気量

\begin{tabular}{|c|c|c|c|c|c|}
\hline \multirow{3}{*}{$\begin{array}{c}\text { 䉓位走查域 } \\
\text { (V) }\end{array}$} & \multirow{3}{*}{$\begin{array}{l}\text { 走植速度 } \\
(\mathrm{V} / \mathrm{sec})\end{array}$} & \multicolumn{4}{|c|}{ 還元西気量 $\left(\mathrm{m} \mathrm{coul} / \mathrm{cm}^{2}\right)$} \\
\hline & & \multicolumn{2}{|c|}{ 電 } & \multicolumn{2}{|c|}{ 位*（V) } \\
\hline & & 0.5 & 0.4 & 0.3 & 0.2 \\
\hline$-0.22 \sim 0.9$ & 0.19 & 0.15 & 0.25 & 0.27 & 0.30 \\
\hline$\sim 1.0$ & 0.18 & 0.23 & 0.35 & 0.40 & 0.43 \\
\hline$\sim 1.1$ & 0.23 & 0.26 & 0.46 & 0.55 & 0.59 \\
\hline$\sim 1.2$ & 0.16 & 0.25 & 0.57 & 0.70 & 0.75 \\
\hline$\sim 1.3$ & 0.19 & 0.23 & 0.56 & 0.75 & 0.82 \\
\hline$\sim 1.4$ & 0.19 & 0.26 & 0.63 & 0.87 & 0.96 \\
\hline
\end{tabular}

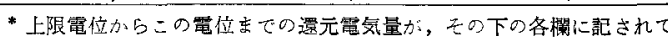
レ3.

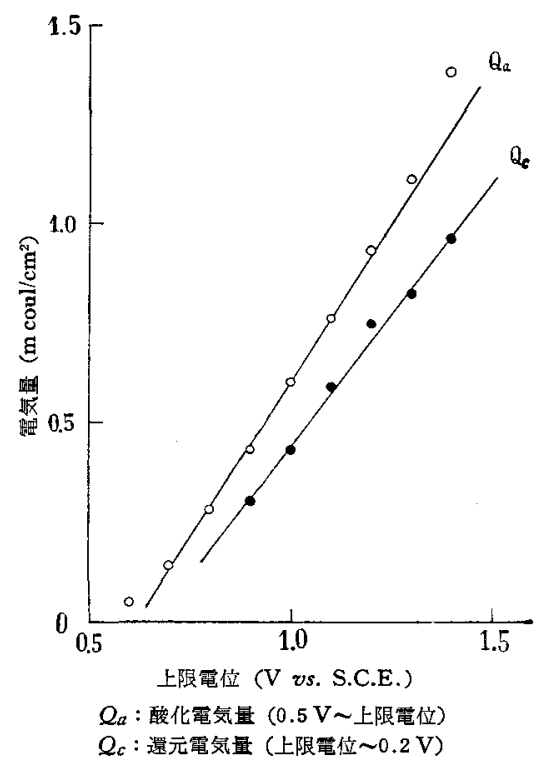

図 6 走查上限電位之電気量の関係

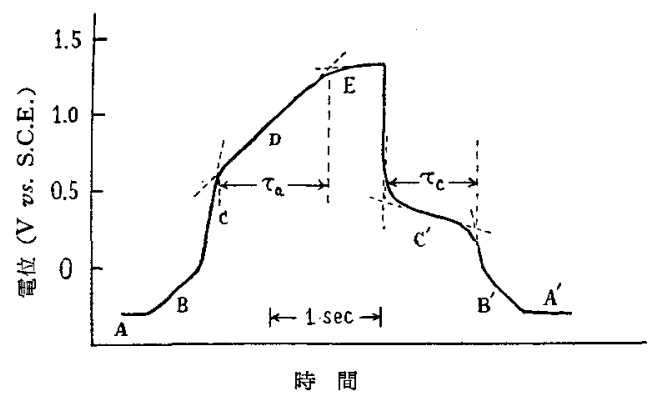

図7 $1 \mathrm{~N} \mathrm{H}_{2} \mathrm{SO}_{4}$ 中に扎ける白金電極のクロノポテン シオグラム $\left(i=1.28 \mathrm{~mA} / \mathrm{cm}^{2}\right)$

シオグラムを示した.アノード過程では，吸着水素の酸 化域 (B), 電気二重層の充電域 (C), 表面酸化層の生成 域 (D) を経て酸素発生に至り，カソード過程では，表 面酸化層の還元域 $\left(\mathrm{C}^{\prime}\right)$ ，水素イオンの還元之吸着 $\left(\mathrm{B}^{\prime}\right)$ の過程を順次経過しており，三角波による電位-電流曲線 において見られる現象とよく対応している。

クロノポテンシオグラムでは, 表面酸化層生成域で電 位変化が時間に対して值線的となっている，てのてう配
から酸化層形成反応の微

分容量を求めると $1.4 \times$ $10^{3} \mu \mathrm{F} / \mathrm{cm}^{2}$ が得られ（表 2), 図5における $1.0 \mathrm{~V}$, または図6における $Q_{a}$ の直線のてう配から同樣 な微分容量の計算がで きそれぞれ $1.4 \times 10^{3}$ $\mu \mathrm{F} / \mathrm{cm}^{2}, 1.6 \times 10^{3} \mu \mathrm{F} / \mathrm{cm}^{2}$ が得られる。との点でも 三角波ポテンシオメトリ 一とクロノポテンシオメ

表 2 酸化層生成電位域に おける $d Q / d E$

\begin{tabular}{|c|c|c|}
\hline $\begin{array}{c}\text { 電 流 } \\
\left(\mathrm{mA} / \mathrm{cm}^{2}\right)\end{array}$ & $\begin{array}{c}d Q / d E \\
\left(\times 10^{3} \mu \mathrm{F} / \mathrm{cm}^{2}\right)\end{array}$ & 備 \\
\hline 0.64 & 1.3 & \multirow{5}{*}{ 空気眗和 } \\
\hline 0.64 & 1.5 & \\
\hline 1.28 & 1.7 & \\
\hline 1.28 & 1.2 & \\
\hline 2.56 & 1.2 & \\
\hline 0.64 & 1.6 & \multirow{4}{*}{ 窒䒺飽和 } \\
\hline 0.64 & 1.8 & \\
\hline 1.28 & 1.5 & \\
\hline 2.56 & 1.2 & \\
\hline 平均 & 1.4 & \\
\hline
\end{tabular}

トリーとの一致はよい。

酸化層生成，還元に要する電気量は図 7 での遷移時間 $\tau_{a}, \tau_{c}$ 值接比例するべきすのである，種々の電流密度 で行なったクロノポテンシオメトリーの結果は， $\tau_{a}$ 㔔常 に $\tau_{c}$ よりも 2 3 割程度大である.これについては， 後の考察で触れる。

\section{3 考察}

三角波ポテンシオメトリーの結果からも，クロノポテ ンシオメトリーの結果加らも，酸化首生成化要する電気 量は電位と直線関係仙ある，完成される表面屏が従来い われているように単分子層であるとするならば，被覆率 $\theta$ が電位と直線関係侸るととになる。この上うな関係 は，電荷受授過程が平衡にあり，先行または後秸する吸 着過程が全反応を律速している場合には，吸着の速度式 に $d \theta / d t=a e^{-b \theta * 1}$ を導入するてとによってみちびくて とができるし，また不可逆的な電荷授受過程の反柭速度 定数 $(k)$ が $k=k_{0} \exp (-2 \theta)$ のごとく，速度定数そのも のが被覆率 $\theta$ によって変化すると考兊らるならば，直接 的に $(E+$ const $) \propto \theta$ の関係をみちびくことができる*2。

前者，すなわち吸着速度による解秎は一つの考元方で

*1これは Elovich の式 ${ }^{12)}$ と呼ばれ，表面か沟一でなく，吸着の活性化工

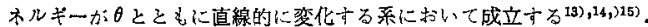

いま, 電荷授受通程を $\mathrm{H}_{2} \mathrm{O} \rightarrow \mathrm{O}+2 \mathrm{H}^{+}+2 \mathrm{e}$, 吸着過程を $\mathrm{Me}+\mathrm{O}$ $\rightarrow \mathrm{MeO}$ であると仮定するならば，前者には，Nernst 式が適用でき るとしてもよいであるらから，

$E=E_{0}+(R T / 2 F) \ln a_{0} a^{2} \mathrm{H}^{+}$

末た後者について结，

$i=q_{0}(d \theta / d t)=a_{0} k_{1} \exp (-\lambda \theta)$

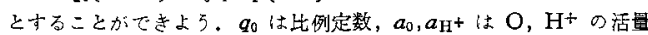
$k_{1}, \lambda$ は定数である。両式より次式か得られる。 $d \theta / d t=\frac{1}{a^{2} \mathrm{H}^{+}} k \exp (-\lambda \theta) \exp (2 F E / R T)$

ここで $k=\left\{k_{1} \exp \left(-2 F E_{0} / R T\right)\right\} / q_{0}$ で苦る。実駼条件 $\left(E=v_{0} t+\right.$ const，恋たは $i=$ const）を考慮し， $a_{\mathrm{H}^{+}}$の変化が無視できるものと

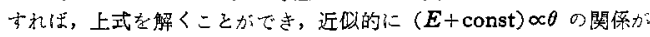
得られる。.

*2この仮定は，三角波ポテンンオメトリーの場合 $i=q_{0}(d \theta / d t)=k \exp (-\lambda \theta) \exp (d n F E / R T)$ クロノポテンシオメトリーの場合

$i=$ const $=q_{0}(d \theta / d t)=k \exp (-\lambda \theta) \exp (\alpha n F E / R T)$ と㧍くこと意味する。 
はあるが，酸化尿形成の問題については素過程のとり方 に検討の余地があるし，より一般的な後者の考光方につ いては定数 $\lambda$ の内容について, さらに吟味の必要がある と思われる。

アノード過程における酸化層生成に要する電気量と， そのカソード過程での還元電気量とについて，望月 ${ }^{10)}$ や，Knorr ${ }^{8)}$ は，それらが等量であるとしているが，著 者らの結果では, 明らか酸化に要する電気量の方が多 い. 同様な事実は Pt,Pd,Au の各金属について Vetter ${ }^{6)}$ も認めており，蒩いのない事実である．との理由として は,

1）白金の溶解が起とるか，吸着酸素の電極面からの 離脱が生ずる、これを溶離説と呼んでおこう。

2）酸化反応と還元反応の電子数が異なる異種反応機 構説.

とが考えられる。

金の表面酸化層について著者らの行なったクロノポテ ンシオメトリーによると, 酸化電気量と還元電気量の比 は，印加電流密度と密接な関係汇あり，金の酸化層が自 発的に一定速度で溶解するものとしてよく説明できると とを示しだ6)*. 図4 にわいて,カソード還元の生しな い電位領域で走查を繰り返してみると，二回目以降にる 電流は零とならず一定值を示すとと，図 5 で $1.0 \mathrm{~V}$, $1.2 \mathrm{~V}$ (酸化屏の形成の行なわれている電位)で電流と 走查速度の関係をみると, 走査速度に無関係な電流が存 在することなどは，白金の場合にも1）の理由を考えて もよい証拠と思われる。

クロノポテンシオメトりーによるVetter の研究で は $^{6)}, \mathrm{Pt}, \mathrm{Pd}$ で $Q_{a} \div 2 Q_{c}$ であったことから,アノード 過程では，

$$
\mathrm{Me}+\mathrm{H}_{2} \mathrm{O} \rightarrow \mathrm{Me}-\mathrm{O}+2 \mathrm{H}^{+}+2 \mathrm{e}
$$

カソード過程では，

$$
2 \mathrm{Me}-\mathrm{O}+2 \mathrm{H}^{+}+2 \mathrm{e} \rightarrow 2 \mathrm{Me}+\mathrm{H}_{2} \mathrm{O}_{2}
$$

として, 両反応に関与する白金 1 原子当たりの電子数の 相違に原因を求めている. 酸素の還元過程で過酸化水素 の生成することはよく知られた事実であり，逆の酸化過 程で過酸化水素を检出した報告は知られていないなどの 事実を考虑すると, Vetter の機構を否定するととはで きない.しかし, 本報の結果では, $Q_{a} \fallingdotseq 1.2 Q_{\varepsilon}$ の程度

*かだ，金酸化物が浴解するか，酸菜のみか、離脱するかを区別するこ とは，著者らの実駼からはできない，前埌では金酸化物の溶解として

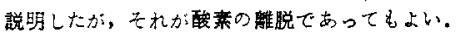

であって，ちょうど二倍の関係にはない，先に，述へた 溶離説とした方が，金の事実とも一致して罗当と思われ る.

\section{4 総 括亡結語}

三角波ポテンシオメトリー，およびクロノポテンシオ メトリーによって, 硫酸溶液中の白金電極の表面酸化買 の挙動を検討した結果，

1）アノード過程での電位は, 酸化層の被覆率に比例 する。

2)これは，電荷授受過程に先行または後続する吸着 過程が全反応を律速する場合，あるいは電荷授受過 程の速度定数が $k=k_{0} \exp (-\lambda \theta)$ で表わされる場合 として説明できる。

3）酸化層形成に要する電気量は，その還元に要する 電気量より常に大である。

4)これは，酸化㯰形成開始とともに，酸素の離脱ま たは金属酸化層の溶解が生ずるためと考元られる。

終わりに，本研究の一部を担当した浅井工君は，本年 9 月 24 日不虑の事故により死亡した。本報を公表する ことにより故人への手向けとしたい。

なお，本研究は一部を文部省科学研究費によって行な った.

(昭 38-12-6 受理)

\section{文献}

1) A. Hickling, Trans. Faraday Soc. 41, 333 (1945).

2) S.E.S. ElWakkard, S.H. Emara, J. Chem. Soc. 1952, 461 (1952).

3) I.M. Kolthoff, N. Tanaka, Anal. Chem. 26, 632 (1954).

4) F. Anson, J.J. Lingane, J. Am. Chem. Soc. 79, 4901 (1957).

5) E. Lange, G. Rädlen,Z. Elektrochem. 61, 724, 727 (1957).

6) K.J. Vetter, D. Berndt, ibid. 62, 37? (1958).

7) J. Giner, ibid. 63, 386 (1959).

8) F.G. Will, C. Knorr, ibid. 64, 258, $270(1960)$.

9) H.A. Laitinen, C.G. Enke, J. Electrochem. Soc. 101, 773 (1960).

10）望月政司，本誌 28，583 (1960)。

11) M.W. Briiter, J.L. Weininger, J. Electrochem. Soc. 109 1135 (1962).

12) S. Yu. Elovich, G.M. Zhabrova, Zhur. fiz. Kim. 13, 1761, 1775 (1939).

13) H.A. Taylor, N. Thon, J. Am. Chem. Soc. 74, 4169 (1952).

14) A.S. Porter, F.C. Tompkins, Proc, Roy. Soc. A 211, 529 (1953).

15）溞川 裕, 触婪 2, 434 (1960).

16) K. Asai, K.Ohashi, K. Sasaki, S. Nagaura, Memoirs of the Faculty of Engineering, Osaka City University, 5 , 181 (1963). 